\title{
Studies on Digestion Coefficients and Rumen Fermentation of some Improved Rations by Males of Sinai Sheep and Goats
}

\author{
Tharwat, R. A. ${ }^{1,2}$; E. S. Soliman ${ }^{2}$; M. El-Gayar ${ }^{1 *}$; M. Yaseen $^{1}$ and M.A. Ayoub ${ }^{1}$ \\ ${ }^{1}$ Department of Animal Production, Faculty of Agriculture, Suez Canal University, Ismailia, Egypt \\ ${ }^{2}$ Animal Production Research Institute, Agriculture Research Centre, Dokki, Giza, Egypt
}

Received: $14 / 8 / 2019$

\begin{abstract}
In order to improve the productivity of Sinai sheep and goats, the effects of feeding with mineral mixture additives (experiment 1) and the mixture of mineral with alfalfa (experiment 2 ) on the digestion coefficients (dry matter (DM), organic matter (OM), crude protein (CP), crude fiber (CF), ether extract (EE) and nitrogen free extract (NFE)), nutritive values (total digestible nutrients (TDN) and digestible crude protein (DCP)) and rumen fermentation were evaluated. Experiment 1 was applied to evaluate two rations ( 1 and 2). Ration 1 contained concentrate feed mixture (CFM) and wheat straw (ratio 2:1) and ration 2 contained CFM with additive of $0.2 \%$ mineral mixture and wheat straw. Experiment 2 was applied to evaluate two rations (A and B). Ration A contained CFM, Alfalfa and wheat straw and ration $\mathrm{B}$ contained CFM mixed with $0.2 \%$ mineral mixture additive, Alfalfa and wheat straw. Three Sinai rams and three Sinai bucks aged 2-3 years were used. The rumen parameters as $\mathrm{pH}$, ammonia-N, Volatile fatty acids, microbial protein and protozoa were measured in rumen fluid at 0,2 and 4 hours after feeding. Results of experiment 1 indicated that the differences of digestion coefficients of nutrients between ration 1 and ration 2 were not significant, while the EE digestibility in ration $2(55.6 \%)$ was significantly higher $(\mathrm{P}<0.05)$ than ration $1(53.3 \%)$ in the sheep. The digestion coefficients of DM $(65.1 \%)$ and $\mathrm{OM}(67.1 \%)$ in ration 2 were significantly higher $(\mathrm{P}<0.05)$ than ration $1(62.5 \%$ and $64.1 \%$, respectively) in the goats. The digestion coefficients of CF (58.6\%) and EE (58.5\%) of ration B were significantly higher $(\mathrm{P}<0.05)$ than ration $\mathrm{A}(56.5 \%$ and $56.2 \%$, respectively) in the sheep. The digestion coefficients of DM (67.4\%) and OM (68.6\%) in ration B were significantly higher $(\mathrm{P}<0.05)$ than ration $\mathrm{A}(65.7 \%$ and $67.1 \%$, respectively) in the goats. In sheep, NFE of ration B was significantly $(\mathrm{P}<0.05)$ lower than ration $\mathrm{A}(70.4 \%$ and $72.9 \%$, respectively). In goats, TDN values were significantly $(\mathrm{P}<0.05)$ higher in ration 2 than ration $1(64.3 \%$ and $63.1 \%$, respectively) and also in ration $\mathrm{B}$ than ration $\mathrm{A}\left(64.9 \%\right.$ and $62.4 \%$, respectively). The difference of $\mathrm{NH}_{3}-\mathrm{N}_{\text {at }} 4 \mathrm{~h}$ post feeding in rumen of goats was significantly $(\mathrm{P}<0.05)$ lower in ration 2 than ration $1(17.7 \mathrm{mg}$ and $21 \mathrm{mg}$ per $100 \mathrm{ml}$ rumen liquid, respectively). The lowest values $(\mathrm{P}<0.05)$ of $\mathrm{pH}$ were recorded at $4 \mathrm{~h}$ after feeding in both breeds. In sheep, microbial protein (MP) in the rumen fluid was significantly $(\mathrm{P}<0.05)$ higher in ration $\mathrm{B}$ than ration $\mathrm{A}(0.90 \mathrm{~g}$ and $0.84 \mathrm{~g}$ per $100 \mathrm{ml}$ rumen liquid, respectively). It could be concluded that using of the mixture of mineral additives (N.Candles $\subset$ Pharm) in feeding Sinai sheep and goats can improve the digestion coefficients, nutritive values and rumen fermentation. Further studies in this area are recommended to evaluate effect of mineral additives on animal performance and its economical return.
\end{abstract}

Keywords: Sheep, goats, mineral, alfalfa, digestibility, rumen.

\section{INTRODUCTION}

Sheep and goats are important animals in Sinai Peninsula (Alsheikh, 2013). Sinai Peninsula is an arid region and its natural vegetation is nutritionally poor in quantity and quality (Shkolnik et al., 1972). Some studies noticed that trace minerals additives improved digestibility (Salama et al., 2003; Fathul and Wajizah, 2010; Xun et al., 2012; Abd El-Hafez et al., 2016; Ibrahim, 2017). However, Kwak et al. (2016) and Pino and Heinrichs (2016) found that, digestibility was not affected by mineral additives. On the other hand, some studies explained that some rumen parameters may be affected by mineral additives. Mousa and Orabi (2014) found that rumen $\mathrm{pH}$ value was lower with mineral premix additives at $4 \mathrm{~h}$ post feeding. Shi et al. (2011) and Xun et al. (2012) found that rumen $\mathrm{pH}$ values were lower with Selenium (Se) supplementation in the diet, however some studies reported that $\mathrm{pH}$ values were not significantly affected by mineral mixture additives (El Ashry et al., 2012; Deng et al., 2013). Deng et al. (2013) found that rumen ammonia $-\mathrm{N}$ of goats was significantly increased by feeding with mixture of Sodium, Zinc and Manganese than without additives. Xun et al. (2012) found that, ammonia-N concentration was significantly decreased with Se supplementation to sheep rations. However, Kwak et al. (2016) found that rumen ammonia-N was not affected with supplementation of trace minerals mixture. Deng et al. (2013) found that the total of rumen volatile fatty acids of goats was significantly increased by feeding with mixture of Sodium, Zinc and Manganese than without additives at 2 and $4 \mathrm{~h}$ post feeding, however the differences at $0,6,8$ and $10 \mathrm{~h}$ were not significant. Xun et al. (2012) found that total volatile fatty acids concentration was significantly increased with Se supplementation to sheep rations containing alfalfa hay. Shi et al. (2011) noticed that total volatile fatty acids concentration was higher in rumen of sheep fed the diet supplemented with $0.3 \mathrm{mg} \mathrm{Se} / \mathrm{kg} \mathrm{DM}$, however Engle and Spears (2000), Spears et al. (2004), Fathul and Wajizah (2010) and Kwak et al. (2016) noticed that total volatile fatty acids concentration was not affected in the rumen with minerals additives.

Minerals are one of the important components associated with production and reproduction of animals (Khan et al., 2014). Nawito et al. (2015) found that trace mineral levels were low in blood of sheep and goats grazing in Sinai. The poor nutrition level of Sinai 
sheep and goats are causing low rates of their production and reproduction. Therefore, sustainable sources of feed resources especially high quality forage crops which are tolerant to soil salinity and drought are necessarily needed in Sinai such as alfalfa (Fayed et al., 2010; Abd El-Naby et al., 2013; Mohamed et al., 2013; Al-Geldawy, 2014). Therefore, the present study aimed to evaluate some rations with or without mineral mixture additives on digestibility, nutritive values and rumen fermentation parameters by Sinai sheep and goats.

\section{MATERIALS AND METHODS}

This study was carried out at the Animal Production Experimental Farm and laboratories of Animal Production Department, Faculty of Agriculture, Suez Canal University. Three Sinai rams aged 2 - 3 years and averaged weight $44 \pm 1.42 \mathrm{~kg}$ and three Sinai bucks aged 2 - 3 years and averaged weight $37 \pm 1.33 \mathrm{~kg}$ were used. Animals were individually housed in separate pens. Four experimental rations were evaluated in this study in two experiments. Experiment 1 was applied to evaluate two rations (1 and 2). Ration 1 contained concentrate feed mixture (CFM) and wheat straw (ratio 2:1) and ration 2 contained CFM with additive of $0.2 \%$ mineral mixture and wheat straw. Experiment 2 was applied to evaluate two rations (A and B). Ration A contained CFM, Alfalfa and wheat straw and ration $\mathrm{B}$ contained CFM mixed with $0.2 \%$ mineral mixture additive, Alfalfa and wheat straw. The rations in experiment 1 and 2 were isocaloric and isonitrogenous according to NRC 1985 for sheep and 1981 for goats.

The composition of CFM is yellow maize $(57 \%)$, soybeen meal $(15 \%)$, wheat bran $(25.5 \%)$, lime stone $(2 \%)$, common salt $(0.5 \%)$ and anti-toxic $(0.1 \%)$. The chemical compositions of CFM, wheat straw and alfalfa are shown in Table (1). The main values of DM, $\mathrm{OM}, \mathrm{CP}, \mathrm{CF}, \mathrm{EE}, \mathrm{NFE}$ and ash for rations are presented in Table (2).

Table (1): Chemical composition of CFM, Alfalfa and Wheat Straw

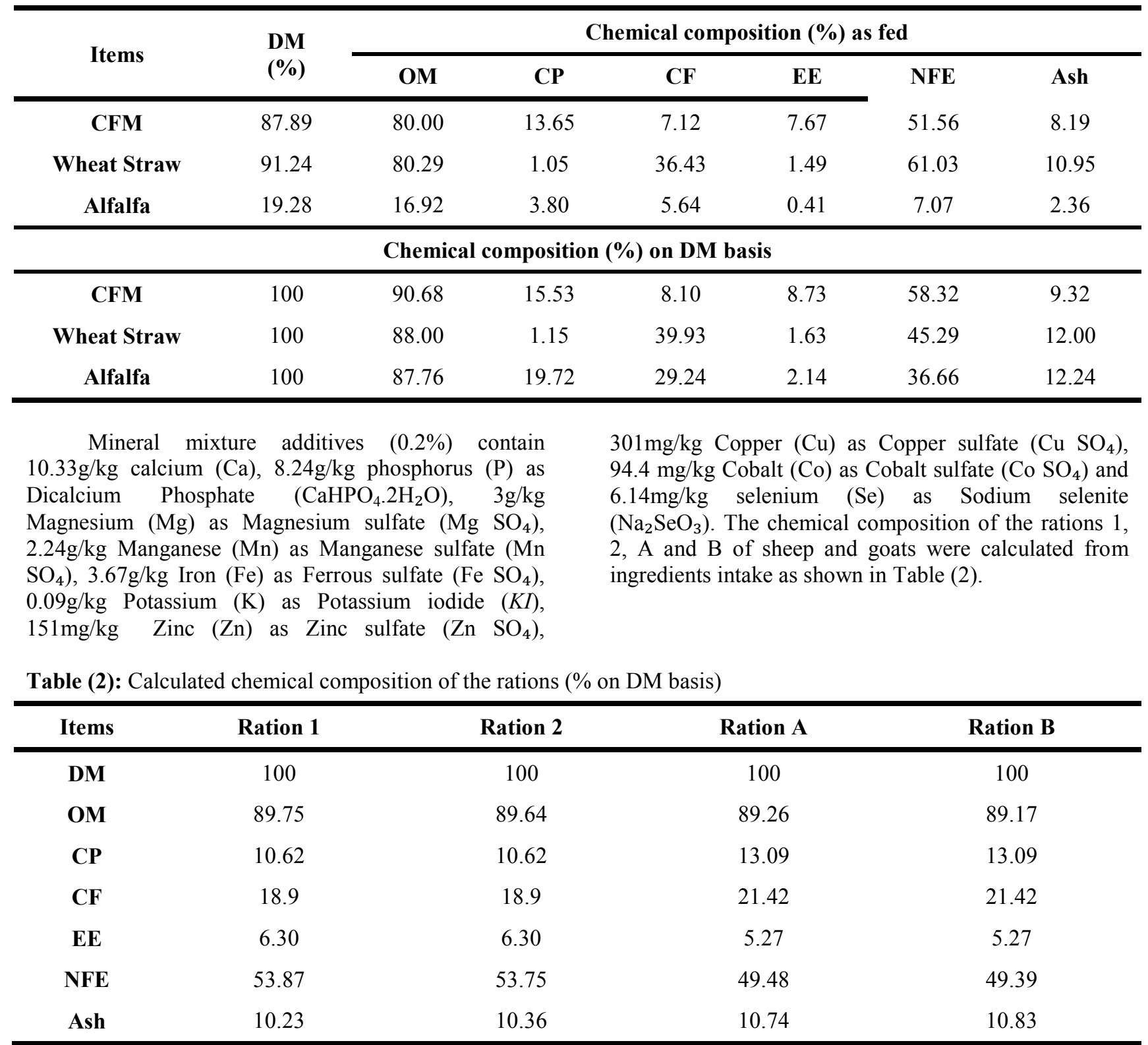


The amounts of rations were divided into two equal amounts and offered to animals daily at 8:00 am and 4:00 pm. The water was available at all times. The digestibility trials were carried out for determining the digestion coefficients of feed nutrients and consequently calculate nutritive values of the rations. The digestibility trial and rumen parameters lasted 36 days as 7 days adaptation period, 21 days preliminary period, 5 days for collection period of samples and 3 days for rumen parameters. Representative samples of food and faeces were subjected to chemical analysis for determination of $\mathrm{DM}, \mathrm{OM}, \mathrm{CP}, \mathrm{CF}, \mathrm{EE}$, ash and NFE following the methods of AOAC (1985). The total digestible nutrients (TDN) and digestible crude protein (DCP) were calculated. The digestibility was carried out by acid insoluble ash (AIA) as a natural marker according to Van Keulen and Young (1977). Fresh feces samples were collected for five consecutive days and dried in oven at $65^{\circ} \mathrm{c}$ for $24 \mathrm{~h}$, then mixed, and used as representative samples. The feed and feces samples were milled to pass through a $1 \mathrm{~mm}$ screen and stored in plastic bags for chemical analysis. Rumen fluid samples were taken by using a stomach plastic tube at 0 time (before feeding), 2 and 4 hours post feeding. These samples were filtered through three layers of surgical gauze without squeezing. Ruminal $\mathrm{pH}$ was immediately estimated by digital $\mathrm{pH}$ meter. Rumen ammonia-N $\left(\mathrm{NH}_{3}-\mathrm{N}\right)$ was determined according to Conway (1957). Total volatile fatty acids (TVFA's) were measured by the steam distillation method as described by Warner
(1964). Total number of protozoa was counted by using Fuchs Rosenthal chamber. Rumen microbial protein was determined according to Shultz and Shultz (1970).

Data were subjected to statistical analysis by using SPSS (2011) program. Differences among treatment means were tested for significance $(p<0.05)$ using Duncan' multiple range test (Duncan, 1955).

The mathematical model as the follows:

$\mathrm{Yij}=\mu+\mathrm{Ti}+\mathrm{eij}$

Where:

Yij = Individual observation.

$\mu=$ The overall mean for the trial under consideration.

$\mathrm{Ti}=$ The effect of the $\mathrm{i}$ treatments.

eij $=$ Random residual error.

\section{RESULTS}

The digestion coefficients and nutritive values as total digestible nutrients (TDN and DCP) of rations in the experiment 1 of sheep and goats are shown in Table (3). The differences of digestion coefficients of all nutrients and nutritive values as TDN and DCP of sheep between ration 1 and ration 2 were not significant except EE digestibility of ration 2 was significantly $(\mathrm{P}<0.05)$ higher than ration 1 . The digestion coefficients of $\mathrm{DM}$ and $\mathrm{OM}$ and TDN of goats of ration 2 were significantly $(\mathrm{P}<0.05)$ higher than ration 1 , while the differences of CF, EE and NFE digestibility and DCP between ration 1 and ration 2 were not significant.

Table (3): Digestion coefficients and nutritive values of the rations fed by sheep and goats in the experiment 1

\begin{tabular}{|c|c|c|c|c|}
\hline \multirow[b]{2}{*}{ Items } & \multicolumn{2}{|c|}{ Sheep } & \multicolumn{2}{|c|}{ Goats } \\
\hline & Ration 1 & Ration 2 & Ration 1 & Ration 2 \\
\hline \multicolumn{5}{|c|}{ Digestion coefficients, \% } \\
\hline $\mathbf{D M}$ & $66.29 \pm 1.58$ & $66.90 \pm 1.29$ & $62.45^{\mathrm{b}} \pm 0.25$ & $65.11^{\mathrm{a}} \pm 0.23$ \\
\hline OM & $67.35 \pm 1.62$ & $68.21 \pm 1.25$ & $64.07^{b} \pm 0.51$ & $67.11^{\mathrm{a}} \pm 0.24$ \\
\hline $\mathbf{C P}$ & $64.91 \pm 0.48$ & $66.30 \pm 0.33$ & $60.25 \pm 0.58$ & $61.62 \pm 0.43$ \\
\hline CF & $54.50 \pm 0.53$ & $55.97 \pm 0.75$ & $53.33 \pm 1.01$ & $54.98 \pm 0.34$ \\
\hline EE & $53.27^{\mathrm{b}} \pm 0.40$ & $55.60^{\mathrm{a}} \pm 0.31$ & $47.44 \pm 1.23$ & $49.68 \pm 1.05$ \\
\hline NFE & $75.64 \pm 0.21$ & $75.77 \pm 0.38$ & $74.09 \pm 2.13$ & $74.91 \pm 1.56$ \\
\hline \multicolumn{5}{|c|}{ Nutritive values, \% } \\
\hline TDN & $65.45 \pm 0.23$ & $66.27 \pm 0.30$ & $63.09^{\mathrm{b}} \pm 1.63$ & $64.30^{\mathrm{a}} \pm 0.76$ \\
\hline DCP & $6.81 \pm 0.05$ & $6.96 \pm 0.34$ & $6.33 \pm 0.32$ & $6.47 \pm 0.27$ \\
\hline
\end{tabular}

The digestion coefficients and nutritive values of the experiment 2 of sheep and goats are presented in Table (4). The differences of digestion coefficients of DM, OM, CP and TDN and DCP of sheep between ration $A$ and ration $B$ were not significant, while the $C F$ and $\mathrm{EE}$ digestibility were significantly $(\mathrm{P}<0.05)$ higher and NFE digestibility was significantly $(\mathrm{P}<0.05)$ lower in ration $\mathrm{B}$ than ration $\mathrm{A}$. The digestion coefficients of $\mathrm{DM}$ and $\mathrm{OM}$ and TDN of goats of ration $\mathrm{B}$ were significantly $(\mathrm{P}<0.05)$ higher than ration $\mathrm{A}$, while the differences of digestion coefficients of $\mathrm{CP}, \mathrm{CF}, \mathrm{EE}$ and $\mathrm{NFE}$ and DCP between ration $\mathrm{A}$ and ration $\mathrm{B}$ were not significant. 
Table (4): Digestion coefficients and nutritive values of the rations fed by sheep and goats in the experiment 2

\begin{tabular}{ccccc}
\hline & \multicolumn{2}{c}{ Sheep } & Goats \\
\cline { 2 - 5 } Items & Ration A & Ration B & Ration A & Ration B \\
\hline DM & $67.25 \pm 0.54$ & Digestion coefficients, \% & $67.40^{\mathrm{a}} \pm 0.30$ \\
OM & $69.25 \pm 0.53$ & $67.47 \pm 0.56$ & $65.67^{\mathrm{b}} \pm 0.52$ & $68.55^{\mathrm{a}} \pm 0.29$ \\
CP & $69.64 \pm 0.77$ & $69.72 \pm 0.77$ & $67.11^{\mathrm{b}} \pm 0.44$ & $69.74 \pm 2.21$ \\
CF & $56.46^{\mathrm{b}} \pm 0.34$ & $69.97 \pm 1.04$ & $68.71 \pm 2.26$ & $57.84 \pm 1.49$ \\
EE & $56.16^{\mathrm{b}} \pm 0.50$ & $58.61^{\mathrm{a}} \pm 1.05$ & $56.91 \pm 0.06$ & $55.53 \pm 0.38$ \\
NFE & $72.92^{\mathrm{a}} \pm 0.51$ & $58.48^{\mathrm{a}} \pm 0.78$ & $53.99 \pm 0.38$ & $72.10 \pm 1.24$ \\
\hline TDN & $63.22 \pm 0.69$ & $70.35^{\mathrm{b}} \pm 0.45$ & $72.79 \pm 1.33$ & $64.90^{\mathrm{a}} \pm 0.93$ \\
\hline DCP & $9.16 \pm 0.25$ & Nutritive values, $\%$ & & $9.31 \pm 0.43$ \\
\hline
\end{tabular}

a and $b$ means in the same rows with different superscripts are significantly different $(\mathrm{P}<0.05)$

The rumen $\mathrm{pH}$, ammonia- $\mathrm{N}\left(\mathrm{NH}_{3}-\mathrm{N}\right)$, TVFA's, MP and protozoa in the experiment 1 of sheep and goats are shown in Table (5). The differences of $\mathrm{pH}$ and $\mathrm{NH}_{3}-$ $\mathrm{N}$ in the rumen fluid of sheep or goats between rations 1 and 2 were not significant except the $\mathrm{NH}_{3}-\mathrm{N}$ at $4 \mathrm{~h}$ post feeding in rumen of goats was significantly $(\mathrm{P}<0.05)$ lower in ration 2 than ration 1 . On the other hand, the
$\mathrm{pH}$ values were significantly $(\mathrm{P}<0.05)$ lower and $\mathrm{NH}_{3}-\mathrm{N}$ values were significantly $(\mathrm{P}<0.05)$ higher at $2 \mathrm{~h}$ and $4 \mathrm{~h}$ than $0 \mathrm{~h}$ after feeding in sheep and goats. The differences of total volatile fatty acids (TVFA's), microbial protein (MP) and protozoa numbers in the rumen fluid of sheep or goats between ration 1 and ration 2 were not significant.

Table (5): $\mathrm{pH}$, ammonia-N $\left(\mathrm{NH}_{3}-\mathrm{N}\right)(\mathrm{mg} / 100 \mathrm{ml})$, total VFA's $(\mathrm{mEq} / 100 \mathrm{ml}), \mathrm{MP}(\mathrm{g} / 100 \mathrm{ml})$ and protozoa numbers $\left(\times 10^{3} / \mathrm{ml}\right)$ in rumen fluid of sheep and goats in the experiment 1

\begin{tabular}{cccccc}
\hline \multirow{2}{*}{ Items } & Time & \multicolumn{2}{c}{ Sheep } & \multicolumn{2}{c}{ Goats } \\
\cline { 3 - 6 } & $\mathbf{0}$ & $6.60^{\mathrm{A}} \pm 0.05$ & $6.57^{\mathrm{A}} \pm 0.02$ & $7.22^{\mathrm{A}} \pm 0.04$ & $7.21^{\mathrm{A}} \pm 0.02$ \\
$\mathbf{p H}$ & $\mathbf{2}$ & $6.46^{\mathrm{A}} \pm 0.15$ & $6.25^{\mathrm{B}} \pm 0.81$ & $6.56^{\mathrm{B}} \pm 0.07$ & $6.48^{\mathrm{B}} \pm 0.08$ \\
& $\mathbf{4}$ & $5.97^{\mathrm{B}} \pm 0.05$ & $5.91^{\mathrm{C}} \pm 0.09$ & $6.37^{\mathrm{B}} \pm 0.09$ & $6.35^{\mathrm{B}} \pm 0.12$ \\
& $\mathbf{0}$ & $18.05 \pm 1.12$ & $17.11^{\mathrm{B}} \pm 0.82$ & $14.93^{\mathrm{B}} \pm 1.43$ & $13.69^{\mathrm{B}} \pm 1.36$ \\
NH $_{\mathbf{3}}-\mathbf{N}$ & $\mathbf{2}$ & $21.93 \pm 1.68$ & $19.60^{\mathrm{A}} \pm 1.62$ & $20.53^{\mathrm{A}} \pm 0.93$ & $18.04^{\mathrm{A}} \pm 2.24$ \\
& $\mathbf{4}$ & $21.16 \pm 2.04$ & $19.13^{\mathrm{A}} \pm 0.47$ & $21.00^{\mathrm{aA}} \pm 0.81$ & $17.73^{\mathrm{bA}} \pm 0.93$ \\
TVFA's & $\mathbf{4}$ & $8.22 \pm 0.22$ & $9.44 \pm 0.30$ & $8.66 \pm 0.66$ & $9.38 \pm 0.66$ \\
MP & $\mathbf{4}$ & $0.73 \pm 0.03$ & $0.79 \pm 0.03$ & $0.73 \pm 0.02$ & $0.77 \pm 0.04$ \\
Protozoa & $\mathbf{2}$ & $247.222 \pm 27.64$ & $262.778 \pm 22.62$ & $262.333 \pm 19.73$ & $290.556 \pm 20.73$ \\
\hline
\end{tabular}

${ }^{\mathrm{a} \text { and }}{ }^{\mathrm{b}}$ means in the same rows with different superscripts are significantly different $(\mathrm{P}<0.05)$.

$\mathrm{A}, \mathrm{B}$ and $\mathrm{C}$ means in the same column with different superscripts are significantly different $(\mathrm{P}<0.05)$.

The rumen $\mathrm{pH}$, ammonia- $\mathrm{N}\left(\mathrm{NH}_{3}-\mathrm{N}\right)$, TVFA's, $\mathrm{MP}$ and protozoa in the experiment 2 of sheep and goats are presented in Table (6). The differences of $\mathrm{pH}$ values at all times in the rumen fluid of sheep between ration $\mathrm{A}$ and ration $\mathrm{B}$ were not significant, while the $\mathrm{pH}$ values in the rumen fluid of goats were significantly $(\mathrm{P}<0.05)$ lower in ration $\mathrm{B}$ than ration $\mathrm{A}$. On the other hand, the $\mathrm{pH}$ values of sheep and goats were significantly $(\mathrm{P}<0.05)$ lower at 2 and $4 \mathrm{~h}$ post feeding than $0 \mathrm{~h}$. The lowest $(\mathrm{P}<0.05)$ values of $\mathrm{pH}$ were recorded at $4 \mathrm{~h}$ after feeding in both breeds. The differences of $\mathrm{NH}_{3}-\mathrm{N}$ in the rumen fluid of sheep or goats between ration $\mathrm{A}$ and ration $\mathrm{B}$ were not significant. The highest values $(\mathrm{P}<0.05)$ of $\mathrm{NH}_{3}-\mathrm{N}$ were recorded at $2 \mathrm{~h}$ post feeding. The differences of TVFA's and protozoa numbers in the rumen fluid of sheep or goats between ration $\mathrm{A}$ and ration $\mathrm{B}$ were not significant. The $\mathrm{MP}$ in the rumen fluid of sheep was significantly $(\mathrm{P}<0.05)$ higher in ration $\mathrm{B}$ than ration $\mathrm{A}$, while the difference of MP in goats was not significant. 
Table (6): $\mathrm{pH}$, ammonia-N $\left(\mathrm{NH}_{3}-\mathrm{N}\right)(\mathrm{mg} / 100 \mathrm{ml})$, total VFA's $(\mathrm{mEq} / 100 \mathrm{ml}), \mathrm{MP}(\mathrm{g} / 100 \mathrm{ml})$ and protozoa numbers $\left(\times 10^{3} / \mathrm{ml}\right)$ in rumen fluid of sheep and goats in the experiment 2 .

\begin{tabular}{cccccc}
\hline \multirow{2}{*}{ Items } & Time & \multicolumn{2}{c}{ Sheep } & Goats \\
\cline { 3 - 6 } & & Ration A & Ration B & Ration A & Ration B \\
\hline pH & $\mathbf{0}$ & $7.60^{\mathrm{A}} \pm 0.07$ & $7.49^{\mathrm{A}} \pm 0.08$ & $7.67^{\mathrm{aA}} \pm 0.02$ & $7.32^{\mathrm{bA}} \pm 0.06$ \\
& $\mathbf{2}$ & $6.86^{\mathrm{B}} \pm 0.09$ & $6.80^{\mathrm{B}} \pm 0.14$ & $7.07^{\mathrm{aB}} \pm 0.03$ & $6.52^{\mathrm{bB}} \pm 0.07$ \\
& $\mathbf{4}$ & $6.52^{\mathrm{C}} \pm 0.05$ & $6.50^{\mathrm{C}} \pm 0.05$ & $6.67^{\mathrm{aC}} \pm 0.02$ & $6.18^{\mathrm{bC}} \pm 0.06$ \\
NH $_{3}-\mathbf{N}$ & $\mathbf{2}$ & $32.61^{\mathrm{A}} \pm 0.51$ & $31.73^{\mathrm{A}} \pm 0.93$ & $32.67^{\mathrm{A}} \pm 0.47$ & $32.46^{\mathrm{A}} \pm 0.58$ \\
& $\mathbf{0}$ & $30.64^{\mathrm{A}} \pm 1.32$ & $28.93^{\mathrm{A}} \pm 0.47$ & $30.18^{\mathrm{B}} \pm 1.25$ & $29.33^{\mathrm{B}} \pm 0.78$ \\
TVFA's & $\mathbf{4}$ & $10.00 \pm 0.80$ & $11.34 \pm 1.23$ & $10.66 \pm 0.66$ & $11.34 \pm 0.66$ \\
MP & $\mathbf{4}$ & $0.84^{\mathrm{b}} \pm 0.02$ & $0.90^{\mathrm{a}} \pm 0.01$ & $0.88 \pm 0.01$ & $0.89 \pm 0.01$
\end{tabular}

$\mathrm{a}$ and $\mathrm{b}$ means in the same row with different superscripts are significantly different $(\mathrm{P}<0.05)$.

$\mathrm{A}, \mathrm{B}$ and $\mathrm{C}$ means in the same column with different superscripts are significantly different $(\mathrm{P}<0.05)$.

\section{DISCUSSION}

The results of the present study revealed that mineral mixture supplementation had slightly improved digestion coefficients and nutritive values especially $\mathrm{EE}$ digestibility of sheep in experiment 1 and $\mathrm{CF}$ and EE, and NFE digestibility of sheep experiment 2, also DM and OM digestibility and TDN of goat in both experiments. These results agreed with the results obtained by Fathul and Wajizah (2010). Salama et al. (2003) showed that $\mathrm{Zn}$ supplementation increased digestibility of DM and OM of goats. However, Kwak et al. (2016) and Pino and Heinrichs (2016) found that the digestion coefficients of DM, OM, CP, EE, CF and $\mathrm{NFE} \%$ were not affected by additives of trace minerals. The obtained data showed that TDN values were significantly increased with mineral additives of the goat in both experiments. Abd El-Hafez et al. (2016) found that Se additive significantly increased TDN. As essential component of the antioxidant defense system, Se plays a role in metabolism through their participation in enzyme reactions (Willshire and Payne, 2011). The role of Se in improving nutrient digestibility could relate to its effect on increasing rumen microbial population and activity (Faixova et al., 2007 and Xun et al., 2012). However, Ibrahim (2017) found that TDN and DCP were not affected with Se supplementation. The improvement of NFE digestibility might be due to $\mathrm{Cu}$ enhanced ruminal fermentation (Engle and Spears, 2000).

The rumen $\mathrm{pH}$ is affected by fermentation products in the rumen, therefore, the $\mathrm{pH}$ is the most direct and important parameter reflecting rumen fermentation status (Prasad et al., 1972). The variation of rumen $\mathrm{pH}$ is affected by dietary composition and nutrient levels (Russell and Rychlik, 2001). In this study the data explained that $\mathrm{pH}$ values in the both experiments ranged from 5.91 to 7.1 after feeding. The mineral addition did not significantly affect $\mathrm{pH}$ values except the $\mathrm{pH}$ in ration $\mathrm{B}$ was significantly lower than ration $\mathrm{A}$ in goats. These results agreed with those obtained by Deng et al. (2013) who found that rumen $\mathrm{pH}$ values were not significantly affected by feeding with mineral mixture. Mousa and Orabi (2014) found that $\mathrm{pH}$ value was lower at $4 \mathrm{~h}$ post feeding with mineral premix additive. Also Osman et al. (2007) found that the lowest $\mathrm{pH}$ values recorded at $2 \mathrm{~h}$ post feeding, while Saleh (2003) and Shakweer (2003) noticed that the lowest ruminal $\mathrm{pH}$ values were recorded at $3 \mathrm{~h}$ post feeding. Fathul and Wajizah (2010) found that the addition of copper and manganese did not affect ruminal $\mathrm{pH}$. The decrease in $\mathrm{pH}$ values after feeding may be due to the increasing in TVFA's production in the rumen. The $\mathrm{NH}_{3}-\mathrm{N}$ values in this study increasing after feeding until $21.93 \mathrm{mg} / 100 \mathrm{ml}$ in sheep rumen fluid in the experiment 1 and $32.67 \mathrm{mg} / 100 \mathrm{ml}$ in goats rumen fluid in the experiment 2 at $2 \mathrm{~h}$ post feeding. The data obtained in this study explained that the differences of $\mathrm{NH}_{3}-\mathrm{N}$ in the rumen fluid of sheep or goats between ration 1 and ration 2 were not significant except the $\mathrm{NH}_{3}-\mathrm{N}$ at $4 \mathrm{~h}$ post feeding in rumen of goats was significantly lower in ration 2 than ration 1 . The NH3-N values were significantly higher at $2 \mathrm{~h}$ and $4 \mathrm{~h}$ than $0 \mathrm{~h}$ in sheep and goats. Qi et al. (1992), Fathul and Wajizah (2010) and Kwak et al. (2016) found that mineral additives did not affect ruminal $\mathrm{NH}_{3}-\mathrm{N}$. However, Xun et al. (2012) found that ruminal ammonia $\mathrm{N}$ was significantly decreased with Se supplementation. In this study, the increasing in $\mathrm{NH}_{3}-\mathrm{N}$ in the experiment 2 than the experiment 1 may be due to the high percent of protein in alfalfa consumed by animals in the experiment 2. Also, the highest values of $\mathrm{NH}_{3}-\mathrm{N}$ were recorded at $2 \mathrm{~h}$ for goats post feeding. These results agreed with those obtained by Osman et al. (2007). However, Saleh (2003) found that the highest $\mathrm{NH}_{3}-\mathrm{N}$ values were recorded at $3 \mathrm{~h}$ post feeding, while Shakweer (2003) found that the highest $\mathrm{NH}_{3}-\mathrm{N}$ values 
were recorded at $6 \mathrm{~h}$ post feeding. Generally the $\mathrm{NH}_{3}-\mathrm{N}$ values in the rumen are affected by values feed nitrogen and degradability of nitrogen sources to $\mathrm{NH}_{3}$. The TVFA's are the main end products of the fermentation of carbohydrates in the rumen. The total VFA's in these study ranged from 8.22 to $9.44 \mathrm{mEq} / 100 \mathrm{ml}$ rumen fluid in the experiment 1 and ranged from 10.00 to 11.34 $\mathrm{mEq} / 100 \mathrm{ml}$ rumen liquor in the experiment 2 . The effect of mineral mixture additives on TVFA's production in the rumen was not significant. These results agreed with those obtained by Engle and Spears (2000), Spears et al. (2004), Fathul and Wajizah (2010) and Kwak et al. (2016). However, Zhang et al. (2007), Shi et al. (2011), Xun et al. (2012) and Deng et al. (2013) found that total of TVFA's concentration was increased in the rumen with mineral supplementation. Generally, the production of TVFA's in the rumen depends on dietary composition, rumen environment and microbial population (Weimer, 1998). The rumen microbial protein (MP) in this study ranged from 0.73 to $0.79 \mathrm{gm} / 100 \mathrm{ml}$ rumen fluid in the experiment 1 and ranged from 0.84 to $0.90 \mathrm{gm} / 100 \mathrm{ml}$ rumen fluid in the experiment 2 . The highest values of MP in experiment 2 than experiment 1 may be due to the high production of $\mathrm{NH}_{3}$ in the rumen. Or-Rashid et al. (2001) stated that ammonia-N concentration in the rumen directly influences microbial protein synthesis. In both experiments, mineral additives were not significantly affect MP production in the rumen except MP in rumen of sheep fed ration B was significantly higher than ration A. Sonawane and Arora (1976) noticed that the microbial protein synthesis was increased with additional Zn. Also, Se supplementation may increase the ruminal microbial protein synthesis as effective ruminal degradability and the nutrient digestion in the total tract was improved and increased ruminal VFA concentration and switched rumen fermentation pattern from acetate to propionate (Xun et al., 2012). Se supplementation could increase rumen microbial population and activity (Mihaliková et al., 2005, Faixova et al., 2007 and Wang et al., 2007). The reduction of ammonia-N concentration by $\mathrm{Se}$ supplementation could be due to an enhanced growth of ruminal microbial populations which increased the ammonia N consumption (Xun et al., 2012). Generally, the synthesis of microbial protein depends on different factors such as roughage: concentrate ratio in the diet, the sources of carbohydrates and proteins, the level of voluntary intake, the rumen recycle of microbes and the synchronization of nutrient releaseinthe rumen as stated by Rodríguez et al. (2007). In both experiments, results showed that the mineral additives were not significantly affecting rumen protozoa. Generally, the count and species of the rumen protozoa were influenced by several factors such as composition of the diet, rumen $\mathrm{pH}$, frequency of feeding and level of feeding as reported by Santra and Karim (2002).

\section{CONCLUSION}

It would be concluded that using of the mixture of mineral additives (N.Candles $\subset$ Pharm) in feeding males of Sinai sheep and goats may improve the digestion coefficients, nutritive values and rumen fermentation. Mineral mixture could be added $(0.2 \%)$ to the rations contained concentrate feed mixture and wheat straw with or without alfalfa. Further studies in this area are recommended to evaluate effect of mineral additives on animal performance and its economical return.

\section{REFERENCES}

Abd El-Hafez, G. A., G. M. A. Solouma, A. Y. Kassab and A. S. Ali (2016). Some reproductive performance of male lambs and feeding values of rations as affected by supplementation of different Se sources. Egyptian J. Nutrition and Feeds, 19(1): 103114.

Abd El-Naby, Z. M., A. M. Sallam and N. A. Mohamed (2013). Evaluating yield and quality of three alfalfa cultivars using laboratory and saline affected soil. J. American Sci., 9(12): 5-14.

Alsheikh, S. M. (2013). Characterization of livestock production system in south Sinai, Egypt. J. Anim. Prod., 4(7): 411 - 417.

Al-Geldawy, A. R. (2014). Study of using alfalfa in sheep rations on feeding and reproductive performance. M. Sc. Thesis, fac. Agric. Suez Canal University.

AOAC, (1985). Official Methods of Analysis. $15^{\text {th }}$ Edition, Association of Official Analytical Chemists, Official Methods of Analysis, Washington, D.C., USA. p:69-84.

Conway, E. J. (1957). Microdiffusion analysis and Volumetric Error Rev. Ed. Lockwood, London.

Deng, H. W. Y. Y. Cong, Y. L. Feng and J. Chen (2013). Effects of dietary supplementation with different sulfate sources on nitrogen and sulfur metabolism and rumen fermentation in cashmere goats. Livestock Research for Rural Development, 25(3). LRRD Newsletter

Duncan, D. B. (1955). Multiple range and multiple F tests. Biometrics, 11: 1-42.

El Ashry, G. M. A. A. Hassan and M. S. Soliman (2012). Effect of feeding a combination of Zinc, Manganese and Copper Methionine Chelates of early lactation high producing Dairy Cow. Food and Nutr. Sci., 3: 10841091.

Engle, T. E. and J. W. Spears (2000). Dietary copper effects on lipid metabolism, performance, and ruminal fermentation in finishing steers. J. Anim. Sci., 78: 2452-2458

Faixova, Z., S. Faix, L. Leng, P.Vaczi, Z. Makova and R. Szaboova (2007). Hematological, blood and rumen chemistry changes in lambs following supplementation with se-yeast Acta. Vet. Brno, 76: 3-8.

Fathul, F. and S. Wajizah (2010). Additional micromineral $\mathrm{Mn}$ and $\mathrm{Cu}$ in relation to rumen biofermentation activities of sheep in vitro method. Indonesian, J. Anim. and Viter. Sci. (JITV), 15(1): 9-15. 
Fayed, A, M., A. M. El- Essawy, E.Y. Eid, H. G. Helal, A., R. Abdou and H. M. El Shaer (2010). Utilization of Alfalfa and Atriplex for Feeding Sheep under Saline Conditions of South Sinai, Egypt. J. of American Sci., 6 (12):1447-1461.

Ibrahim, E. M. (2017). Effect of parenteral supplementation of vitamin $\mathrm{E}$ plus $\mathrm{Se}$ on nutrient digestibility, productive performance and some serum biochemical indicators of lambs. Egypt. J. sheep \& Goat Sci., 12(1): 59-70.

Khan, H. M., M. Bhakat, T. K. Mohanty and T. K. Pathbanda (2014). Influence of vitamin E, macro and micro minerals on reproductive performance of cattle and buffalo- a review. Agri. Review, 35(2): 113 - 121.

Kwak, W. S., Y. I. Kim, D. Y. Choi and Y. H. Lee (2016). Effect of feeding mixed microbial culture fortified with trace minerals on ruminal fermentation, nutrient digestibility, nitrogen and trace mineral balance in Sheep. J Anim. Sci. Technol., 58: 21-28.

Mihaliková, K., L. Gresaková, K. Boldizarová, S. Faix, L. Leng and S. Kisidayová (2005). The effects of organic selenium supplementation on the rumen ciliate population in sheep. Folia Microbiol. 50: 353-356.

Mohamed, M. M., M. A. El-Nahrawy, M. A. Abdu and S. A. Shams (2013). Development of fodder resources in Sinai: The role of forage crops in Agriculture development, North SinaiGovernorate, Egypt. J. Agron., 12(1): 29-37.

Mousa, S. A. and S. Orabi (2014). Growth performance, rumen fermentation parameters and selected serum macro and micro mineral in Egyptian Steers fed on berseem hay. Global Veterinaria, 13(2): 233-236.

Nawito, M. F., K. G. M. Mahmoud1, M. M. M. Kandiel, Y. F. Ahmed and A. S. A. Sosa (2015). Effect of reproductive status on body condition score, progesterone concentration and trace minerals in sheep and goats reared in South Sinai, Egypt. Afric. J. Biotech., 14(43): 3001-3005.

NRC (1981). National Research Council, Nutrient Requirements of Domestic Animals. Nutrient Requirements of Goats. National Academic Press. Washington, D.C. USA.

NRC (1985). National Research Council, Nutrient Requirements of Domestic Animals. Nutrient requirements of sheep. National Academic Press. Washington, D.C. USA.

Or-Rashid, M., R. Onodera and S. Wadud (2001). Biosynthesis of methionine from homocysteine, cystathionine and homoserine plus cysteine by mixed rumen microorganisms in vitro. Applied Microbiology and Biotechnology, 55: 758764.

Osman, A. A., E. S. Soliman, F. Z. Swidan and A. N. Ismail (2007). Effect of feeding silages contained citrus pulp and some crop residues on digestibility and rumen parameters of sheep. Egyptian J Nutrition and feeds, 10(2) Special issue: $245-262$.

Pino, F. and A. J. Heinrichs (2016). Effect of trace minerals and starch on digestibility and rumen fermentation in diets for dairy heifers. J. Dairy Sci., 99 (4): 2797-2810.

Prasad, J., S. S. Ahlawalia, and E. P. Joshi (1972). Clinico-Biochemical studies in indigestion in cattle and buffaloes. Ind. J. Anim. Sci., 42 (11): 911-914.

Qi, K., C. D. Lu, F. N. Owens and C. J. Lupton (1992). Sulfate supplementation of Angora goats: metabolic and mohair responses. J. Anim. Sci., 70: 2828-2837.

Rodríguez, R., A. Sosa and Y. Rodríguez (2007). Microbial protein synthesis in rumen and its importance to ruminants. Cuban J. Agri. Sci., 41(4): 287-294.

Russell, J. B. and J. L. Rychlik (2001). Factors that alter rumen microbial ecology. Science. 292(5519): 1119-1122.

Salama, A. A., G. Cajat, E. Albanell, X. Such, R. Casals and J. Plaixats (2003). Effects of dietary supplements of zinc methionine on milk production, udder health and zinc metabolism in dairy goats. J. Dairy Res., 70 (1):9-17.

Saleh, S. A. (2003). Effect of different levels of dicalcium phosphate on growing male lambs. J. Agric. \& Env. Sci. Alex. Univ., Egypt., 2 (1): $14-28$.

Santra, A. and S. A. Karim (2002). Influence of ciliate protozoa on biochemical changes profile in the rumen ecosystem. J. of Applied Microbiology, 92: 801-811.

Shakweer, I. M. E. (2003). Effect of chemical and biological treatments of rice straw and sugar can bagsse on their digestibility, nutritive value, ruminal activity and some blood parameters in rams. Egyptian J. of Nutr. and feeds., 6 (Special Issue). Proceeding the $9^{\text {th }}$ Conf. Anim. Nutrition. 14-17 October, Egypt: 925-940.

Shi, L. G., W. J. Xun, W. B. Yue, C. X. Zhang, Y. S. Ren, Q. Liu and Q. Wang (2011). Effect of elemental nano-selenium on feed digestibility, rumen fermentation, and purine derivatives in sheep. Anim. Feed Sci. Technol., 163: 136-142.

Shkolnik, A., A. Borut and J. Choshniak (1972). Water economy of the Bedouin goat. Symp. Zool. Soc. Lond. No. 31: 229-242.

Shultz, T. A. and E. Shultz (1970). Estimation of rumen microbial nitrogen by three analytical methods. J. Dairy Sci., 53: 781-784.

Sonawane, S. N. and S. P. Arora (1976). Influence of Zinc Supplementation on Rumen Microbial Protein Synthesis in in Vitro studies. Indian J. of Anim. Sci., 46: 13-18.

Spears, J. W., P. Schlegel, M. C. Seal and K. E. Lloyd (2004). Bioavailability of zinc from zinc sulfate and different organic zinc sources and their effects on ruminal volatile fatty acid 
proportions. Livestock Prod Sci., 90: 211217.

SPSS (2011). SPSS Statistics for Windows, Version 20.0. Armonk, NY, USA: IBM Corp.

Van Keulen, J. and B. A. Young (1977). Evaluation of acid-insoluble ash as a natural marker in ruminant digestibility studies. J. Anim. sci., 44 (2): $282-287$.

Wang, H., Zhang, J and H. Yu (2007). Elemental selenium at nano size possesses lower toxicity without compromising the fundamental effect on selenoenzymes: comparison with selenomethionine in mice. Free Radic Bio Med., 42:1524-1533.

Warner, A. C. J. (1964). Production of volatile fatty acids in the rumen. Methods of measurements. Nutr. Abstr. \& Rev. B., 34: 339.
Weimer, P. J. (1998). Manipulating ruminal fermentation: A microbial ecological perspective. J. Anim. Sci., 76: 3114-3122.

Willshire, J. A. and J. H. Payne (2011). Selenium and vitamin $\mathrm{E}$ in dairy cows - a review. Cattle Pract., 19: 22-30.

Xun, W., L. Shi, W. Yue, C. Zhang, Y. Ren and Q. Liu (2012). Effect of high-dose nano-selenium and selenium-yeast on feed digestibility, rumen fermentation and purine derivatives in sheep. Biol. Trace Elem Res., 150(1-3): 130-136.

Zhang, W., R. Wang, X. Zhu, D. O. Kleemann, C. Yue and Z. Jia (2007). Effects of Dietary Copper on Ruminal Fermentation, Nutrient Digestibility and Fibre Characteristics in Cashmere Goats. Asian-Aust. J. Anim. Sci., 20(12): 1843-1848.

\section{"دراسنات على معاملات الهضم وتخمرات الكرش لبعض العلائق المحسنة في ذكور الأغنام والماعز السيناوى"

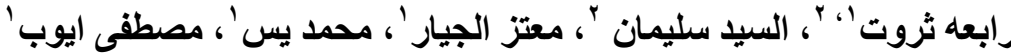

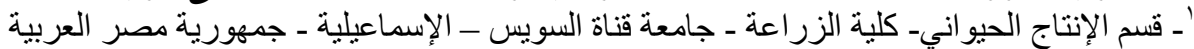

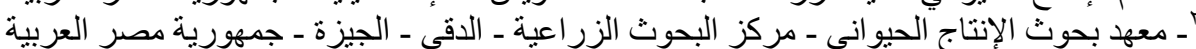

من أجل تحسين إنتاجية الأغنام والماعز في سيناء تم تقييم تأثير التغذية باستخدام إضافات مخلوط الأملاح المعنية (التجربة ( )

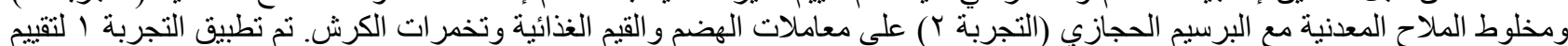

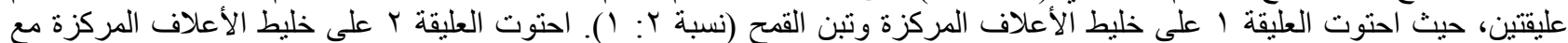

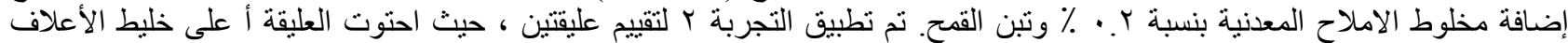

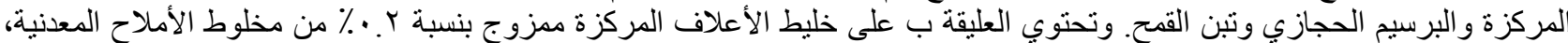

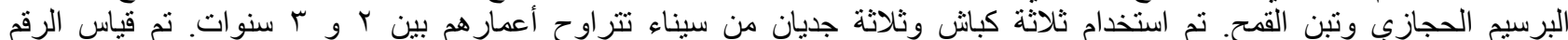

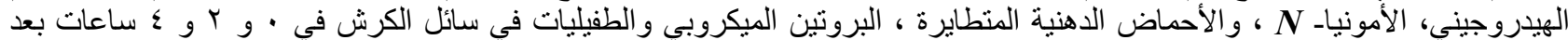

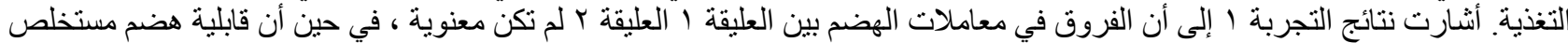

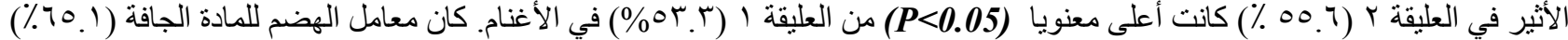

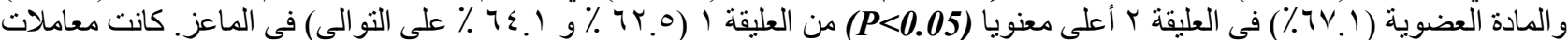

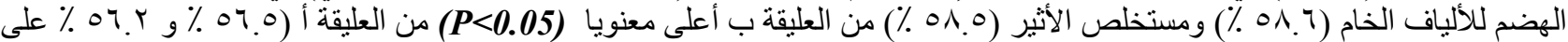

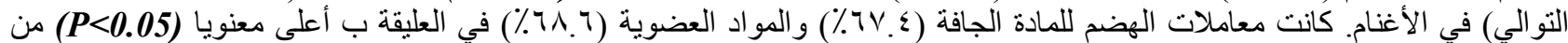

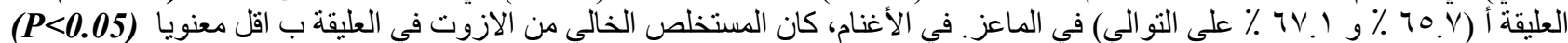

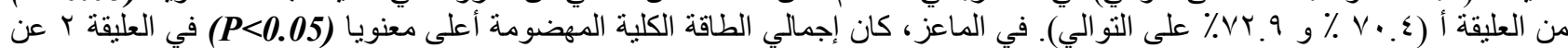

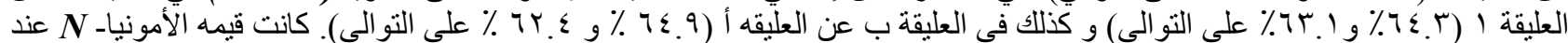

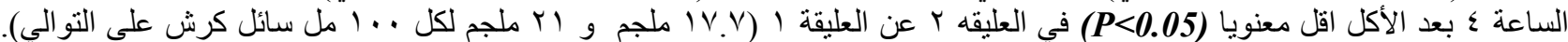

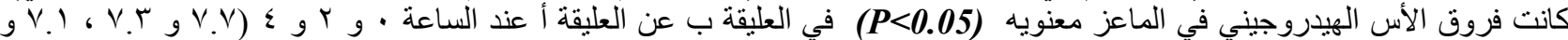

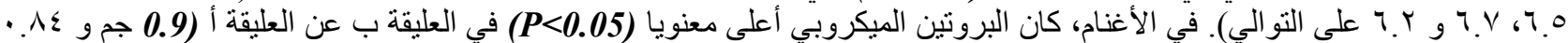

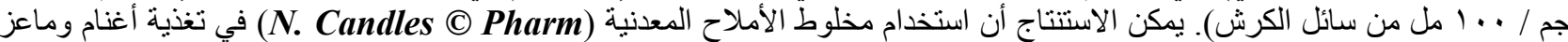

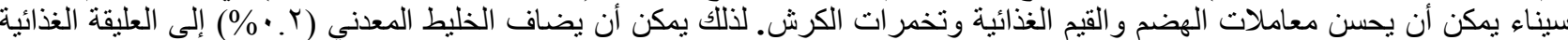

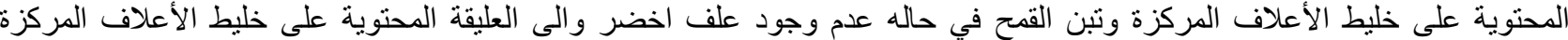

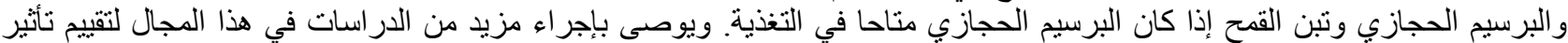
مخلوط الأملاح المعدنية على أداء الحيو انات و عائدها الاقتصادي. 